
\title{
25 Research Square \\ Severe Droughts of 1876-1878 in North China and Possible Causes
}

\section{Zhixin Hao}

Institute of Geogrlnstitute of Geographic Sciences and Natural Resources Research Chinese Academy of Sciences

\section{Mengxin Bai}

Institute of Geographic Sciences and Natural Resources Research Chinese Academy of Sciences

\section{Danyang Xiong}

Institute of Geographic Sciences and Natural Resources Research Chinese Academy of Sciences

\section{Yang Liu}

Institute of Geographic Sciences and Natural Resources Research Chinese Academy of Sciences Jingyun Zheng ( $\nabla$ zhengjy@igsnrr.ac.cn )

Institute of Geographic Sciences and Natural Resources Research Chinese Academy of Sciences

\section{Research Article}

Keywords: Severe droughts, North China, Circumglobal Teleconnection, PDO

Posted Date: February 18th, 2021

DOl: https://doi.org/10.21203/rs.3.rs-161952/v1

License: (c) (i) This work is licensed under a Creative Commons Attribution 4.0 International License. Read Full License

Version of Record: A version of this preprint was published at Climatic Change on July 9th, 2021. See the published version at https://doi.org/10.1007/s10584-021-03127-8. 


\section{Abstract}

Extreme drought of 1876-1878 occurred in most regions of Northern China after the industrial revolution which has led to a series of social impacts, including harvest failure, price inflation, and population immigration. Concurrently, most regions of Northern Hemisphere occurred extreme drought. Here, we used the reconstructed high-resolution hydroclimatic (PDSI/precipitation) datasets, investigated the seasonalannual hydroclimatic spatial patterns and drought intensity with time evolution from 1876 to 1878 in North China. Furthermore, we selected combined Sea Surface Temperature (SST) modes with positive IOD/PDO and El Niño from the 1200-year control run simulations of HadCM3 to diagnose the causes of this severe drought. The extent and intensity of selected SST mode was similar with that in Pacific and Indian Ocean during the 1876-1878 from NOAA/ERSST dataset. The results showed that the large-scale drought of 1876-1878 was mainly driven by El Niño and positive PDO, while the effect of IOD was not significant. El Niño may trigger Circumglobal Teleconnection of Northern Hemisphere, and meridional disturbance of mid-latitude Rossby wave train changed the intensity of trough and ridge, and further blocked water vapor transportation.

\section{Introduction}

Global warming has significant impact on precipitation, especially in terms of changing droughts and severe precipitation spatial patterns (Allan and Soden 2008); observations have shown that as global warming intensified in the past 50 years, eastern and southern Asia, Sahel, Mediterranean and most of southern Africa have witnessed less precipitation, while North America, eastern part of South America, Europe, northern and middle Asia, and eastern Australia have witnessed more precipitation (Dai 2011). Moreover, some regions, like Mediterranean and west Africa, have suffered from more intensified and longer droughts (Dai et al. 2013; IPCC 2013), causing great influence on agricultural production, people's livelihood, adaptation modes, etc. Reports from scientists showed that 250,000 people died of hunger during the 1970s 90s East Africa drought and tens of millions of people had crop failure and confronted with survival pressure (Haywood et al. 2013). During the 1997-2009 Australian drought, to get through which, the Australian government had to cut down commercial and household water consumption by half (Field et al. 2012). China suffered, on average, an annual direct economic loss of 9 billion USD from droughts during 2004-13 (Qin 2015). In addition, evidence shows that as global warming getting more serious in the future, droughts will occur more frequently, more intensely and will last longer (Trenberth et al. 2013; Diffenbaugh 2020).

Throughout the history of past 2000 years, it is not uncommon to find droughts triggering famine, which in return disturbed social stabilities and caused the decline and collapse of civilizations. During the 1580-1610 drought which centered around Anatolia, 50\% of the land governed by the Ottoman Empire suffered from famine and turbulence (Xoplaki et al. 2018). The scarce precipitation that lasted several centuries from 800-1100 was one of the most important causes leading to the fall of Maya civilization (Haug et al. 2003). After that, severe drought caused by monsoon anomaly during middle-to-late 14th and early 15th centuries had related to Angkor civilization demise (Buckley et al. 2010). Besides, the 
Cambodian drought in the middle of the 14th century coincided with the decline of Khmer civilization at Angkor (Cook et al. 2010). In China, some studies suggest that the long-lasting drought of 1160-1245 in southeastern Tibetan Plateau accelerated the demise (AD 1253) of Dali Kingdom (Tan et al. 2018). While the drought occurred in the late Ming dynasty reduced per capita grain output by $20 \%-50 \%$ in most of China's farming areas during the 1520s-1630s, and after the great drought of 1638-41, the Ming dynasty which was established in 1368 was replaced by a new dynasty in 1644 (Zheng et al. 2014).

Since the industrial revolution, famous persisting drought during 1876-78 occurred in hemispheric scale, called Ding-Wu (Chinese Lunar year in Ancient time) Great Famine in Chinese. As a result, Asia, South America and Africa concurrently witnessed consecutive drought for several years, which led to widespread crop failures, global famine, and over 50 million deaths (Buchan 1877; Clarke 1878; Derby 1878; Hunter 1877; Kiladis and Diaz 1986; Moura and Shukla 1981; Yu et al. 2018). Some researchers even believed that among the areas that suffered from this drought, Asian Monsoon Region experienced the two most severe drought years (1877 and 1878) for the past 800 years (Singh et al. 2018) and caused global famine. Other studies found that this drought was one of the most serious climate events in North China for the last 300 years. They utilized the detailed rainfall and snowfall archives from documentary evidences of Qing Dynasty, defined the specific season, spatial coverage, and seasonal precipitation amount for this drought event, and assessed its impact on society, and found that North China had serious summer crop failures, due to which the price of rice rocketed 5-10 times and the population in the region reduced by more than 20 million due to deaths and migrations, the immigration in Shandong province alone reached 3 million (Cook et al. 2010; Ge et al. 2016; Hao et al. 2010).

Most previous studies have addressed that the possible climate mechanism of the 1876-78 drought was related to the abnormal rise of sea surface temperatures in NINO3.4 region of central and eastern equatorial Pacific Ocean (Aceituno et al. 2009; Hao et al. 2010, 2018). However, a few studies have pointed out that such extreme events with powerful regional influence, such as the North China drought of 1877-78, cannot be fully explained by the teleconnection mechanism with ENSO and PDO (Yu et al. 2018); rather, it might be due to a combination of strong El Niño, strong positive phase of Indian Ocean Dipole (1877) and warm North Atlantic SST (Singh et al. 2018), and it could also be related to the solar minimum during the 11-year sunspot cycle (Derby 1878). The causes of this drought have almost nothing in common with those of the 1931-39 great drought in North America (once in a thousand years) (Cook et al. 2014). It is suggested that the climate background for long-lasting severe disasters over a large scale was generally more complicated, and could not be explained with one or two factors (Coast et al. 2015; Erb et al. 2020).

Therefore, we elaborated on the most severe drought occurred during the past 150 years in North China, and systematically reviewed drought events occurred concurrently worldwide, based on which, the study analyzed the possible teleconnection between droughts and climatic modes. With global warming and frequent El Niño events in the future, the results of this study have significance for early warnings of more intense severe climates with longer duration. 


\section{Data Source And Method}

The data used in this study mainly include reconstructed North China precipitation dataset, reconstructed Asian Summer Precipitation, Palmer Drought Severity Index (PDSI)/self-calibrating Palmer Drought Severity Index (scPDSI) datasets for North America and Europe, Extended Reconstructed Sea Surface Temperature dataset and simulation results from HadCM3.

The dataset of North China seasonal precipitation from 1736 to 2000 was reconstructed from Yu (rainfall)-Xue (snowfall)-Fen $(0.32 \mathrm{~cm})$-Cun $(3.2 \mathrm{~cm})$ archive, based on soil infiltration depth model having physical significance, which covered 17 sites of North China with evenly distribution (Hao et al. 2003). It is used in this study to demonstrate the severity of the 1876-1878 droughts over time and the starting and ending seasons, so as to combine the droughts more accurately with the monthly development process of El Niño to diagnose the mechanism. And we calculated accumulated seasonal precipitation anomalies percentage to indicate the departure from the normal condition (mean of 1851-2000), the specific periods include Spring (Sp)-summer (Su) of 1876, Sp-Su-Autumn (Au) of 1876, Sp-Su of 18761877, Sp-Su-Au of 1876-1877, Sp-Su-Au of 1876-1877, Sp-Su of 1876-1878, Sp-Su-Au of 1876-1878, and Sp-Su-Au of $1876-1878$. Winter precipitation only accounts for $5-10 \%$ of the annual rainfall in this region, and thus was not considered here.

The reconstructed Asian Summer (June-August) Precipitation from 1470 to 2013 (Short for RAP, Shi et al. 2018 ) is an integrated reconstruction of 453 tree-ring width chronology and 71 historical dry/wet grades chronology, covering a spatial range of $-8.75-55.25^{\circ} \mathrm{N}$ and $61.25-143.25^{\circ} \mathrm{E}$. The RAP dataset can be used to indicate the drought intensity of Asia, and available at https://www.ncdc.noaa.gov/paleosearch/study/24391.

Cook et al (2010) has reconstructed three inter-continental datasets of PDSI over the Northern Hemisphere, which include the North American Drought Atlas Version 2a (NADA), Old World Drought Atlas (OWDA), and Monsoon Asia Drought Atlas (MADA), and all are available at the website https://www.ncdc.noaa.gov/data-access/paleoclimatology-data/datasets/tree-ring/drought-variability. Among them, the NADA dataset from 1 to 2006 CE uses 602 tree-ring chronologies varied from centuries to millennia length, covering the spatial range of $18.5-62.5^{\circ} \mathrm{N}, 137.5-57.5^{\circ} \mathrm{W}$, with a $2.5^{\circ} \times 2.5^{\circ}$ grid point resolution (updated from Cook et al. 2004). The calibration period is 1928-1978, and the verification period is $1900-1927$ PDSI data developed by Dai et al (2004). The $0.5^{\circ} * 0.5^{\circ}$ gridded OWDA dataset from 1 to 2012 CE uses 106 tree-ring chronologies, covering the spatial range of $27.25-70.75^{\circ} \mathrm{N},-11.75-$ $44.75^{\circ} \mathrm{E}$ (Cook et al. 2015). The calibration period is 1928-1978 and the verification period is 1901-1927 scPDSI data (Schrier et al. 2013). However, for Monsoon Asia Drought Atlas (MADA), since only one original tree ring chronology was available over eastern China, the result has low confidence of PDSI in this region (Yang et al. 2013). Thus, we used RAP dataset to illustrate the hydrological climate condition over Asia, rather than MADA. In addition, the datasets of RAP, NADA and OWDA have different parameters and verification periods, the precipitation and PDSI/SCPDSI reconstructions data were standardized first 
(the reference period of climatology is from 1851 to 2000), and then the departures of drought degree for 1876-1878 in North America, Europe and Asia were calculated.

The Extended Reconstructed Sea Surface Temperature (ERSST) dataset from 1854 to present was developed by National Oceanic and Atmospheric Administration (NOAA), which is a global monthly sea surface temperature dataset with $2^{\circ} \times 2^{\circ}$ grid point, and SST anomaly (SSTA) was calculated by departure from 1971-2000 monthly climatology. The SSTA was averaged when extreme droughts occurred during 1876-1878 in North China (Fig. 1). The El Niño mode, together with positive Pacific Decadal Oscillation (PDO) and Indian Ocean Dipole (IOD) phases are obvious in Fig. 1a. Specifically, the monthly average SSTA over the region of Nino3.4 $\left(5^{\circ} \mathrm{N}\right.$ to $5^{\circ} \mathrm{S}, 170^{\circ} \mathrm{W}$ to $\left.120^{\circ} \mathrm{W}\right)$ was further calculated, which is one of the important ENSO climatic mode indicator. The El Niño event (the 3-month running-average of the NINO3.4 index exceeds $+0.5^{\circ} \mathrm{C}$ ) started from October 1876, and ended at June 1878, totally consecutive 21 months as illustrated in Fig. 1b, which is the longest El Niño episode since 1851 (Aceituno et al. 2009; Hao et al. 2003; Kiladis and Diaz 1986).

Among the models involved in the paleoclimate modelling intercomparing project 3 (PMIP3), HadCM3 (Hadley Centre Coupled Model version 3) has better simulation ability towards the trend of extreme precipitation change and the spatial pattern of precipitation in China (Chen et al. 2014), and well captures the PDO, El Niño and IOD climatic modes (Zhou et al. 2019; Kay and Washington 2008). Here we used a 1200 -years long control run of $\mathrm{HadCM} 32^{\circ} \times 2^{\circ}$ simulation, which indicated that the external forcing are keeping constant, of which, the concentrations of greenhouse gases and aerosols are kept the level of preindustrial era, and the detected extreme precipitation changes may be only attributed to internal variability (Collins et al. 2001). To detect the possible causes of the severe drought, we selected cases based on two different groups of SSTA mode, the one is that 10 cases having consecutive 24-month El Niño mode over Nino3.4 region and positive PDO phase ( $>0.5$ standard deviation of mean value) were selected, and another is that 10 cases having consecutive 24-month El Niño mode over Niño3.4 region and positive IOD phase ( $>0.5$ standard deviation of mean value) were selected. In detail, Nino3.4 region SSTA were from $1.10-2.92^{\circ} \mathrm{C}$ and PDO indices were from $0.41-0.76$ for the 10 cases of El Niño and positive PDO phase. And, Nino3.4 region SSTA were from $1.00-2.71^{\circ} \mathrm{C}$ and IOD indices were from $0.83-$ 2.45 in the 10 cases of El Niño and positive IOD phase. Our aiming is that to detect whether the combinations of long duration of strong El Niño and positive PDO/IOD drive the less precipitation over the Northern Hemisphere, and to identify the regions where the precipitation changes have teleconnection relationship with El Niño. It is noted that standardized precipitation was used to reveal hydroclimatic variation for combining the different datasets having inconsistent units. In addition, the two-tail $t$ test was applied to examine whether the dry/wet and meteorology variables of the 10 cases were significantly higher/lower than normal condition.

\section{Results}




\subsection{The 1876-1878 droughts in North China and Northern Hemisphere}

From seasonal precipitation dataset reconstructed by Yu (rainfall)-Xue (snowfall)-Fen (0.32cm)-Cun $(3.2 \mathrm{~cm})$ archive, Fig. 2a showed that the 1876-1878 drought was the most severe event in North China since the industrial revolution. And, five provinces, i.e., Hebei, Shandong, Shanxi, Shaanxi and Henan, were suffered from this severe drought (Fig. 2b-2g). The drought started from the spring of 1876 and ended at the spring of 1878 (for Henan province, the drought lasted until the end of autumn, 1878). Compared to the summer average precipitation of 1851-2000, precipitation anomaly of 1876 and 1877 was $-23 \%$ and $-45 \%$ respectively; and if precipitation amount of the past 150 years was ranked by an ascending order, 1876 and 1877 took the fifth and the first place respectively. Although the precipitation of the second to fourth place, i.e. 1997, 1986 and 1965, was also scarce, the droughts lasted shorter than those of 1876-1878, therefore, they did not cause serious social influences, such as successive crop failures, sharp price increase, cannibalizing, immigration, etc. Figure 2a illustrated that most severe drought of spring and summer of 1876 occurred over Shanxi and Shaanxi provinces, according to the precipitation anomaly reconstructed from Yu-Xue-Fen-Cun archive in Qing Dynasty. Moreover, reconstructed precipitation anomaly in some cities, such as Taiyuan and Yuncheng in shanxi province, Yanan in Shaaxi province, reached by $-50 \%$. Although most sites showed increasing rainfall in autumn, the drought was not alleviated due to the serious lack of rainfall accumulated from previous seasons. By the spring and summer of 1877 , the drought got worse and the precipitation anomalies at more than half of the sites were lower than $-40 \%$, and the average accumulative precipitation anomaly of the whole region reached $-37 \%$. By autumn of 1877 , the drought was at the most serious situation and the average accumulative precipitation anomaly of the whole region reached $-39 \%$. By the spring of 1878 , precipitation began to increase, which alleviated the drought condition; by the autumn of 1878, the average accumulative precipitation anomaly of the region rose to $-28 \%$. If we do not consider the few sites in the south or the previous cumulative effects, the annual precipitation of 1878 in this region has been exceeded $10 \%$ of the average.

According to historical documents, the records such as "Zhili, Shanxi, Henan, Shaanxi and Shandong provinces were suffered from droughts, and seed-sowing time has been delayed. There is no hope for wheat harvest in spring (AD 1876) ... One more year has to be waited; it is no time for planting wheat in winter (AD 1877), so the farmland would be desolated in spring and summer (AD 1877). There is scarce rainfall since autumn (AD 1877) ... Now it is already passed Cold Dew, so it is too late to sow seeds", "The climate was extreme drought, the migratory locust outbroke in Zhili", "The crop harvest was so bad that the food price went higher and higher, poor people was difficult to make a living", which regularly appeared in the rainfall and snowfall memorials to the emperor during the 1876-1878 in Qing dynasty. Meanwhile, some records also showed although precipitation condition in 1878 has got better, time for sowing seeds has passed, e.g. "It has got rain for three times, and precipitation infiltration depth was about 4 or 5 -cun for each time...however, the planting time has passed and it was impossible to sow the seeds now; in Zhili...due to the drought in the last autumn and winter, most farmers were not able to 
cultivate; for those who did manage to, the crop yield was only about $1 / 10$ or $2 / 10$ of the harvest years...". In terms of duration, spatial coverage and intensity, the 1876-1878 event was considered as the second most serious drought, just ranked after the 1639-1643 (in the late Ming Dynasty) drought by some scholars (Hao et al. 2020). Therefore, Zeng Guoquan, the governor of Jiangxi province, called the drought as "a disaster was never seen in past 200 years."

However, it is worth noting that the 1876-1878 drought was actually a hemispheric-scale disaster. In addition to North China, other areas over Northern Hemisphere have experienced severe droughts too. Figure 3 illustrated the spatial distribution of dry and wet areas in 1876, 1877 and 1878 reconstructed from the NADA, OWDA and RAP datasets. It can be seen that from the Fig. 3, in 1876, South Asia, Northern Europe, the east coast and the great plain of North America have witnessed droughts impacts apart from North China. In 1877, the drought got worse, drought areas in Asia significantly expanded and intensity became more severe; all areas of Asia, except for Northeast, Northwest and Southeast coastal China, and central Asia, were in arid climate conditions. The drought in Europe was kept expanding from south to Mediterranean, leaving only west Europe and coastal countries along the Black Sea in humid climate conditions. The east coast of North America and California was suffered from droughts, while drought intensity over the great plain of North America was alleviated. In 1878, although there were still large areas in Asia suffered from droughts, droughts in North America, Europe, etc. have been alleviated, with only that of Mediterranean still severe.

Droughts in some areas may have started earlier or ended later. In south and north India, the droughts started from 1875 and ended in October 1877, which caused crop failure directly, and affected more than 50 million people. Precipitation anomaly was $-41 \%$ in south India during the 1876 . In 1877, precipitation anomaly was $-27 \%$ in north and east India. And, the center of severe drought was in north India (Mishra et al. 2019). In addition to the regions shown in Fig. 3, extreme drought conditions also concurred over other continents. For example, in South American, drought lasted for three years from 1877 to 1879 along the Northeastern Brazil and in the central Andean highland, and the rainfall was only $33 \%$ of the 18711900 climatological mean value (Aceituno et al. 2009; Pereira et al. 2014;). In addition, extreme drought conditions from 1876 to 1879 affected most of the southern African continent (Nash et al. 2019).

\subsection{Possible causes of extreme drought over Northern Hemisphere}

The simulated hydroclimatic spatial patterns from ensemble means of El Niño and positive IOD phase, and El Niño and positive PDO phase were presented in Fig. 4, based on 10 cases in the context of positive PDO/IOD and El Niño. Consistent dry condition in Eastern China, Indian, Northern Europe and south of Canada, and wet condition in Central Asia, Eastern Europe and Northwest of American were shown in Fig. 4a and 4b. However, large difference was in dry Central Europe and Southwest of America and wet Eastern American when PDO was in positive phase, specially, the drought in Eastern China has stronger intensity and wider spatial coverage than the combination of El Niño and positive IOD modes. Through comparing with reconstructed hydroclimatic pattern, the distribution of hydroclimate for positive PDO and 
El Niño phase of Fig. 4a is much closer to that of the reconstructed dry/wet. This indicates that the hydroclimatic variations in North China and other areas over the Northern Hemisphere in 1876-1878 may be largely affected by El Niño and positive PDO. In addition, for 7 cases in combination of El Niño and positive PDO phase, positive IOD phase occurred simultaneously, which suggested that the positive IOD may play a role in the spatial distribution of precipitation. So, in the following research, 10 cases of El Niño and positive PDO phase was just used to composite analysis. Figure 5 showed the geopotential height anomalies at $200 \mathrm{hPa}, 500 \mathrm{hPa}$ and $700 \mathrm{hPa}$ pressure levels for climatic modes of El Niño and positive PDO. As illustrated in Fig. 5a, several negative anomalies centers were in Southern Europe, east of Eastern Asia, and west of North America at the mid-latitude. Meanwhile, a significant positive anomaly was found over the Atlantic. Comparing with high-troposphere, we noted that consistent positive/negative anomalies corresponded over the same areas at $500 \mathrm{hPa}$ (Fig. 5b) and $700 \mathrm{hPa}$ pressure level (Fig. 5c). Such spatial pattern of geopotential height anomaly was well matching with negative phase of the Circumglobal Teleconnection (CGT) (Ding et al. 2011), which was identified by EOF2 of geopotential height at $200 \mathrm{hPa}$ over the Northern Hemisphere. Eastward wave train in the mid-latitude stimulated by negative CGT strengthened meridional disturbance of Rossby wave and as a result, deepened the trough/ridge development. Specially, northerlies in the post-trough pattern over Eastern Asia may bring a little water vapor from high-latitude continent or the polar and as a consequence, caused less precipitation over this region. On the contrary, southerlies in the post-ridge pattern over Western United States and Southern Europe may be favorable to water vapor transport northward. In addition, from the $500 \mathrm{hPa}$ pressure level (Fig. 5b), Eastern Asia and most of Europe were impacted by positive geopotential height anomaly. Due to air accumulation at this pressure level, the intensified divergent movement and weakened convection, as a result, less precipitation occurred over these areas. However, in the Western United States and Southwestern Europe, negative geopotential height anomaly was more favorable to convergence movement. Intensified convection motion may be likely to bring more precipitation. Figure 6a shows that huge cyclone located in the Northwest Pacific and huge anticyclone located in the Northern Atlantic respectively increased northerlies from boreal to the Eastern Asia and Northern Europe, which was corresponding to geopotential height anomaly. Consequently, these led to less precipitation in above-mentioned areas. However, anomalous southerly from low-latitude may bring more water vapor to the western United States and southern Europe. Accompanied by the development of trough and ridge, the southwesterly was prevailed at west coast of the continent and the northwesterly was prevailed at east coast over mid-latitude of the Northern Hemisphere.

Figure $6 \mathrm{~b}$ shows that inconsistent surface air warming anomalies between land and ocean by the El Niño and positive PDO phase, it may cause large zonal sea level pressure gradient between the North Pacific low anomalies and Asia high anomalies, which may weaken land-sea thermal contrast and intensified northerlies from boreal and as a result, partly offset East Asia Summer Monsoon. Meanwhile, meridional pressure gradient between the mid-Atlantic low anomalies and Northern Europe high anomalies, could decrease the westerly to high latitude Europe. These processes are all unfavorable to precipitation.

Above-mentioned findings suggested that extensive dry conditions over the most of Eastern Asia, Europe, Southwestern United States and India and wet conditions over the Southwestern Europe and Northwest 
of America may be largely regulated by El Niño and positive PDO phase. Meanwhile, negative phase of CGT occurred in mid-latitude stimulated eastward wave train and as a result, deepened the trough/ridge. And hence, there presented southwesterlies in the west of continent and northwesterly in the east. Combing with weaken land-sea thermal contrast induced by sea level pressure anomaly, the joint effects lead to such hydroclimatic variation over the Northern Hemisphere.

\section{Discussions}

According to the analysis of Ding et al $(2005,2010)$, there are two ways for potential causes of development of CGT. The first way is direct effect of El Niño. When SST in the eastern Pacific occurs from negative or weak positive anomaly to significant positive anomaly, strong El Niño may lead to equatorial tropospheric temperature warming and hence, entirely ascend the geopotential height of tropical and subtropical areas. And then, zonal seesaw structure between equator and temperate zone over the Northern Hemisphere is excited by enhancement of Hadley circulation. Additionally, the zonally symmetric component of the atmospheric variability was associated with ENSO and related SST anomalies over the Indo-western Pacific and the tropical Atlantic (Seager et al. 2003; Lau et al. 2005). This may largely stimulate the zonally symmetric wave trains. The joint of meridional seesaw structure and zonally symmetric component may trigger the wave train downstream of Rossby. Figure 4 showed that meridional disturbance of Rossby wave affected trough/ridge due to effect of El Niño. Consequently, it may largely alter water vapor transportation and hydroclimatic variations.

The second way is indirect effect of El Niño. In the above-mentioned content, there are 10 cases (totally 30 years) selected from 1200-year control simulation of HadCM3 under the background of positive PDO and El Niño. Figure 7 shows a negative relationship between Indian Summer Monsoon precipitation and summer Nino3.4 index. And the correlation coefficient is reaching up to $-0.54(p<0.01)$. Some studies have also proposed that Indian Summer Monsoon precipitation may be negatively related with El Niño, through both of proxy-based and instrumental observational-based results (Yu et al. 2018). Importantly, less precipitation in India may decrease the evapotranspiration and hence, decrease sensible heat and increase latent heat through the local feedback of land-air interaction (Erlingis et al. 2019; Stegehuis et al. 2013). Consequently, surface air temperature of India is warming over the continent (Fig. 8). As the strongest continental heat source at low latitude, diabatic heating of local air may lead to baroclinic structure over the troposphere, which causes negative anomaly at $200 \mathrm{hPa}$ pressure level and positive anomaly at $500 \mathrm{hPa}$ pressure level and $700 \mathrm{hPa}$ pressure level (Fig. 5). Baroclinic instability would excite successive downstream cells along the waveguide through Rossby wave. Through two pathways mentioned above, El Niño may trigger CGT and further affect the hydroclimatic spatial pattern over the Northern Hemisphere. It is worth noting that the El Niño episode was started from October of 1876, however, the drought was already started before the occurrence of El Niño episode, thus, other forcing, such as AMO, volcanic eruptions, solar irradiation variation and greenhouse gases, maybe contribute the less precipitation during this gap. Meanwhile, more sensitivity experiments are necessary to be conducted. For instance, comparing more sensitivity experiments forced by a certain factor could 
diagnose the mechanism of 1876-1878 drought in North China and how external forcing and internal variabilities affected severe drought in the future.

Except for the combination of positive PDO/IOD and El Niño, the role of Atlantic Multidecadal Oscillation (AMO) on precipitation in East China was also investigated. For instance, Yang et al (2016) indicated that there was drought in East China excepting the coast of southeastern China in the background of negative AMO mode, while, it was opposite when positive AMO occurred during the 20th warming period. In addition, Zhou et al (2020) suggested that whether in the Medieval Climate Anomaly or in the Little Ice Age, severe drought occurred in North China when AMO mode was positive. These studies indicated that the impact of AMO on precipitation of North China still exist uncertainties, which may be related to the climate background or other driving forcing. So, multi-SSTA modes combinations under different climate background should be considered to comprehensively understand causes of severe drought occurrence in North China and simultaneous hydroclimatic variations in other areas of the Northern Hemisphere. Meanwhile, atmospheric bridge processes also affected precipitation anomaly in North China. For instance, Peng (2018) suggested that positive phase of North Atlantic Oscillation via "North AtlanticEurasian teleconnection pattern" altered anomalous anticyclone at the $850 \mathrm{hPa}$ pressure level over Mongolia-north China, and hence, reduced precipitation in North China.

There were volcanic events with volcanic explosivity index (VEI) 5 in 1875 and VEI 4 in 1876 using volcanic chronology from Global Volcanism Program of the Smithsonian Institute in the United States (https://volcano.si.edu/search_eruption.cfm). Generally, when volcanic eruptions led to surface cooling (Driscoll et al, 2012), the triggered El Niño episode (Ohba et al., 2013; Sun et al., 2019) may lead to anomalous westward and northward movement of western Pacific subtropical high (Shen et al., 2007). Consequently, the East Asian Summer Monsoon (EASM) was weakened and precipitation in monsoon region was decreased (Man et al. 2014; Stevenson et al. 2016).

\section{Conclusions}

The reconstructed precipitation dataset over North China revealed that 1876-1878 drought is a longlasting, intense and large spatial coverage event, the accumulated precipitation amount anomaly from spring of 1876 to autumn of 1877 was $-39 \%$. It was ranked at the first place since the industrial era, and the second place during the past 500 years. Apart from North China, other three sets of hydroclimatic reconstructions from tree rings and historical documents, all simultaneously showed the intense drought over the most regions of Northern Hemisphere, even Africa and South America, which affected crop harvest, food price and immigration. The combination of consecutive 24-month El Niño and positive PDO phase may play major role in this severe drought, and IOD has a certain effect. The negative phase of CGT in mid-latitude stimulated eastward wave train, southwesterlies were prevailed in the west of continent and northwesteries in the east continent, which combined with the weak land-sea thermal contrast, and as a result, caused the 1876-1878 server drought.

\section{Declarations}




\section{Acknowledgement:}

This research was supported by grants (to IGSNRR) from the National Natural Science Foundation of China $(41831174,41671201)$ and the Ministry of Science and Technology of the People's Republic of China (2017YFA0603302).

\section{References}

Aceituno P, Prieto MD, Solari ME et al (2009) The 1877-1878 El Niño episode: associated impacts in South America. Clim Chang 92(3-4):389-416. https://doi.org/10.1007/s10584-008-9470-5

Allan RP, Soden BJ (2008) Atmospheric warming and the amplification of precipitation extremes. Science 321(5895):1481-1484. https://doi.org/10.1126/science.1160787

Buchan A (1877) Meteorology and the Indian famine. Nature 16:425-426. https://doi.org/10.1038/016425b0

Buckley, BM; Anchukaitis, KJ; Penny, D et al (2010) Climate as a contributing factor in the demise of Angkor, Cambodia. Proc Nat Acad Sci USA 107(15):6748-6752. https://doi.org/ 10.1073/pnas.0910827107

Chen XC, Xu Y, Xu CH et al (2014) Assessment of Precipitation Simulations in China by CMIP5 Multimodels. Adv Climate Chang Res 10(3): 217-225. https://doi.org/1673-

1719(2014)10:3<217:CQQQHM>2.0.TX;2-9

Clarke H (1878) The drought. Nature 19:53. https://doi.org/10.1038/019053c0

Collins M, Tett S, Cooper C (2001) The internal climate variability of HadCM3, a version of the Hadley Centre coupled model without flux adjustments. Clim Dynam 17(1):61-81.

https://doi.org/10.1007/s003820000094

Coats S, Cook BI, Smerdon JE, et al (2015) North American Pancontinental Droughts in Model Simulations of the Last Millennium. J Climate 2015, 28(5) :2025-2043.

Cook Bl, Seager R, Smerdon JE et al. The worst North American drought year of the last millennium: 1934 . Geophys Res Lett 41(20):7298-7305. https://doi.org/10.1002/2014GL061661

Cook ER, Woodhouse CA, Eakin CM et al (2004) Long-Term Aridity Changes in the Western United States. Science, 306(5698): 1015-1018. https://doi.org/10.1126/science.1102586

Cook ER, Anchukaitis KJ, Buckley BM et al (2010) Asian monsoon failure and megadrought during the last millennium. Science 328(5977):486-489.https://doi.org/10.1126/science.1185188 
Cook ER, Seager R, Kushnir Y et al (2015) Old World megadroughts and pluvials during the Common Era. Science Adv 1(10): e1500561. https://doi.org/10.1126/sciadv.1500561

Dai AG (2011) Drought under global warming: a review. WIREs Clim Chang 2(1):45-65. https://doi.org/10.1002/wcc.81

Dai AG, Trenberth KE, Qian T (2004) A Global Dataset of Palmer Drought Severity Index for 1870-2002: Relationship with Soil Moisture and Effects of Surface Warming. J Hydrometeorol 18(4): 1117-1130. https://doi.org/10.1175/JHM-386.1

Dai AG (2013) Increasing drought under global warming in observations and models. Nat Clim Chang 3(1):52-58. https://doi:10.1038/NCLIMATE1633

Derby OA (1878) The Rainfall of Brazil and the Sun-Spots. Nature 18:384-385. https://doi.org/10.1038/018384c0

Diffenbaugh NS (2020) Verification of extreme event attribution: Using out-of-sample observations to assess changes in probabilities of unprecedented events. Science Adv 6(12):eaay2368.

https://doi.org/10.1126/sciadv.aay2368

Ding QH, Wang B (2005) Circumglobal teleconnection in the Northern Hemisphere summer. J Climate 18(17): 3483-3505. https://doi.org/10.1175/JCLI3473.1

Ding QH, Wang B, Wallace JM et al (2011) Tropical-Extratropical Teleconnections in Boreal Summer: Observed Interannual Variability. J Climate 24(7): 1878-1896. https://doi.org/10.1175/2011JCLI3621.1

Driscoll S, Bozzo A, Gray LJ, et al (2012) Coupled Model Intercomparison Project 5 (CMIP5) simulations of climate following volcanic eruptions. J Geophys Res Atmos 117, D17105.

https://doi.org/10.1029/2012JD017607

Erb MP, Emile-Geay J, Hakim GJ, et al (2020) Atmospheric dynamics drive most interannual US droughts over the last millennium. Science 6(32), eaay7268. https://doi.org/10.1126/sciadv.aay7268

Erlingis JM, Gourley JJ, Basara JB (2019) Diagnosing Moisture Sources for Flash Floods in the United States. Part II: Terrestrial and Oceanic Sources of Moisture. J Climate 20(8): 1511-1531.

https://doi.org/10.1175/JHM-D-18-0120.1

Field C, Barros V, Stocker T (2012) Managing the Risks of Extreme Events and Disasters to Advance Climate Change Adaptation. 589pp. The Edinburgh Building, Shaftesbury Road, Cambridge CB2 8RU England.

Ge QS, Zheng JY, Hao ZX et al (2016) Recent advances on reconstruction of climate and extreme events in China for the past 2000 years. J Geogr Sci 26(7):827-854. https://doi.org/10.1007/s11442-016-13014 
Hao ZX (2003) Reconstructed precipitation series in the middle and lower reaches of the Yellow River during the past 300 years. Doctoral thesis Submitted to Graduate School of Chinese Academy of Sciences.

Hao ZX, Zheng JY, Wu GF et al (2010) 1876-1878 severe drought in North China: Facts, impacts and climatic background. Chinese Sci Bull 55(26):3001-3007. https://doi.org/10.1007/s11434-010-3243-z

Hao ZX, Yu YZ, Ge QS et al (2018) Reconstruction of high-resolution climate data over China from rainfall and snowfall records in the Qing Dynasty. Wiley Interdiscip Rev Clim Chang 9(3): e517. https://doi.org/10.1002/wcc.517

Hao ZX, Wu MW, Zheng JY, et al (2020) Reconstruction of high-resolution climate data over China from rainfall and snowfall records in the Qing Dynasty. Clim Past 16(1):101-116. https://doi.org/10.5194/cp16-101-2020

Haug GH, Günther D, Peterson LC et al (2003) Climate and the collapse of Maya civilization. Science 299(5613):1731-1735. https://doi.org/10.1126/science.1080444

Haywood JM, Jones A, Bellouin N et al (2013) Asymmetric forcing from stratospheric aerosols impacts Sahelian rainfall. Nat Clim Chang 3(7):660-665. https://doi.org/10.1038/nclimate1857

Hunter WW (1877) Droughts and famines in Southern India. Nature 16:14.

https://doi.org/10.1038/016014a0

IPCC (2013) Climate change 2013: The physical science basis. Contribution of Working Group I to the Fifth Assessment Report of the Intergovernmental Panel on Climate Change. Cambridge University Press, Cambridge, UK

Kay G, Washington R (2008) Future southern African summer rainfall variability related to a southwest Indian Ocean dipole in HadCM3. Geophys Res Lett 35(12): L12701.

https://doi.org/10.1029/2008GL034180

Kiladis GN, Diaz HF (1986) An analysis of the 1877-78 ENSO episode and comparison with 1982-83. Mon Weather Rev 114(6): 1035-1047. https://doi.org/10.1175/1520-

0493(1986)114<1035:AAOTEE>2.0.C0;2

Lau NC, Leetmaa A, Nath MJ et al (2005) Influences of ENSO-Induced Indo-Western Pacific SST Anomalies on Extratropical Atmospheric Variability during the Boreal Summer. J Climate 18(15): 29222942. https://doi.org/10.1175/JCLI3445.1

Man WM, Zhou TJ, Jungclaus JH (2014) Effects of Large Volcanic Eruptions on Global Summer Climate and East Asian Monsoon Changes during the Last Millennium: Analysis of MPI-ESM Simulations. J Climate 27(19):7394-7409. 
Mishra V, Tiwari AD, Aadhar S et al (2019) Drought and Famine in India, 1870-2016. Geophys Res Lett 46(4):2075-2083. https://doi: 10.1029/2018GL081477

Moura AD, Shukla J (1981) On the dynamics of droughts in Northeast Brazil: observations, theory and numerical experiments with a general circulation model. J Atmos Sci 38(12):2653-2675.

https://doi.org/10.1175/1520-0469(1981)038<2653:OTDODI>2.0.C0;2

Nash D, Klein J, Endfield G et al (2019) Narratives of nineteenth century drought in southern Africa in different historical source types. Clim Chang 152(3-4):467-485. https://doi.org/10.1007/s10584-0182352-6

Ohba M, Shiogama H, Yokohata T, et al (2013) Impact of strong tropical volcanic eruptions on ENSO simulated in a coupled GCM. J Climate 26(14), 5169-5182. https://doi.org/10.1175/JCLI-D-12-00471.1

Peng YB (2018) Simulated Interannual Teleconnection Between the Summer North Atlantic Oscillation and Summer Precipitation in Eastern China During the Last Millennium. Geophys Res Lett 45(15):77417747.

Pereira MPS, Justino F, Malhado ACM et al (2014) The influence of oceanic basins on drought and ecosystem dynamics in Northeast Brazil. Environ Res Lett 9(12):124013. https://doi.org/10.1088/17489326/9/12/124013

Qin DH (2015) National report on extreme weather-climate events and disaster risk management and adaptation in China. Science Press, Beijing

Schrier G, Barichivich J, Briffa KR et al (2013) A scPDSI-based global data set of dry and wet spells for 1901-2009. J Geophys Res Atmos 118(10):4025-4048. https://doi.org/10.1002/jgrd.50355

Seager R, Harnik N, Kushnir Y et al (2003) Mechanisms of hemispherically symmetric climate variability. J Climate 16(18): 2960-2978. https://doi.org/10.1175/1520-0442(2003)016<2960:MOHSCV>2.0.C0;2

Shen CM, Wang WC, Hao ZX, et al (2007) Exceptional drought events over eastern China during the last five centuries. Clim Chang 85(3-4), 453-471. https://doi.org/10.1007/s10584-007-9283-y

Shi H, Wang B, Cook ER et al (2018) Asian summer precipitation over the past 544 years reconstructed by merging tree rings and historical documentary records. J Climate 31(19):7845-7861.

https://doi.org/10.1175/jcli-d-18-0003.1

Singh D, Seager R, Cook BI et al (2018) Climate and the Global Famine of 1876-78. J Climate 31(23):9445-9467. https://doi.org/10.1175/JCLI-D-18-0159.1

Stegehuis Al, Vautard R, Ciais P et al (2013) Summer temperatures in Europe and land heat fluxes in observation-based data and regional climate model simulations. Clim Dynam 41(2):455-477. https://doi.org/10.1007/s00382-012-1559-x 
Stevenson S, Otto-Bliesner B, Fasullo J, et al (2016) "El Nino Like" hydroclimate responses to last millennium volcanic eruptions. J Climate 29(8), 2907-2921. https://doi.org/10.1175/JCLI-D-15-0239.1

Sun WY, Wang B, Liu J, et al (2019) How northern high-latitude volcanic eruptions in different seasons affect ENSO? J Climate 32(11), 3245-3262. https://doi.org/10.1175/JCLI-D-18-0290.1

Tan LC, Cai YJ, Cheng H et al (2018) High resolution monsoon precipitation changes on southeastern Tibetan Plateau over the past 2300 years. Quaternary Sci Rev 195:122-132.

https://doi.org/10.1016/j.quascirev.2018.07.021

Trenberth KE, Fasullo JT (2013) An apparent hiatus in global warming? Earth Future 1(1):19-32. https://doi.org/10.1002/2013EF000165

Xoplaki E, Luterbacher J, Wagner S et al (2018) Modelling climate and societal resilience in the Eastern Mediterranean in the last millennium. Hum Ecol 46(3):363-379. https://doi.org/10.1007/s10745-0189995-9

Yang FM, Shi F, Kang SY et al (2013) Comparison of the dryness/wetness index in China with the Monsoon Asia Drought Atlas. Theor Appl Climatol 114(3-4): 553-566. https://doi.org/10.1007/s00704013-0858-4

Yang Q, Ma ZG, Fan XG, et al (2016) Decadal Modulation of Precipitation Patterns over Eastern China by Sea Surface Temperature Anomalies. J Climate 30(17):7017-7033.

Yu E, King MP, Sobolowski S (2018) Asian droughts in the last millennium: a search for robust impacts of Pacific Ocean surface temperature variabilities. Clim Dynam 50(11-12):4671-4689.

https://doi.org/10.1007/s00382-017-3897-1

Zheng JY, Xiao LB, Fang XQ et al (2014) How climate change impacted the collapse of the Ming dynasty? Clim Chang 127(2):169-182. https://doi.org/10.1007/s10584-014-1244-7

Zhou XC, Jiang DB, Lang XM (2019) A multi-model analysis of 'Little Ice Age' climate over China. The Holocene, 29(4): 592-605. https://doi.org/10.1177/0959683618824761

Zhou XC, Lang XM, Jiang DB (2020) Teleconnections between the Atlantic Multidecadal Oscillation and eastern China summer precipitation during the Medieval Climate Anomaly and Little Ice Age. The Holocene 30(12):1694-1705.

\section{Figures}



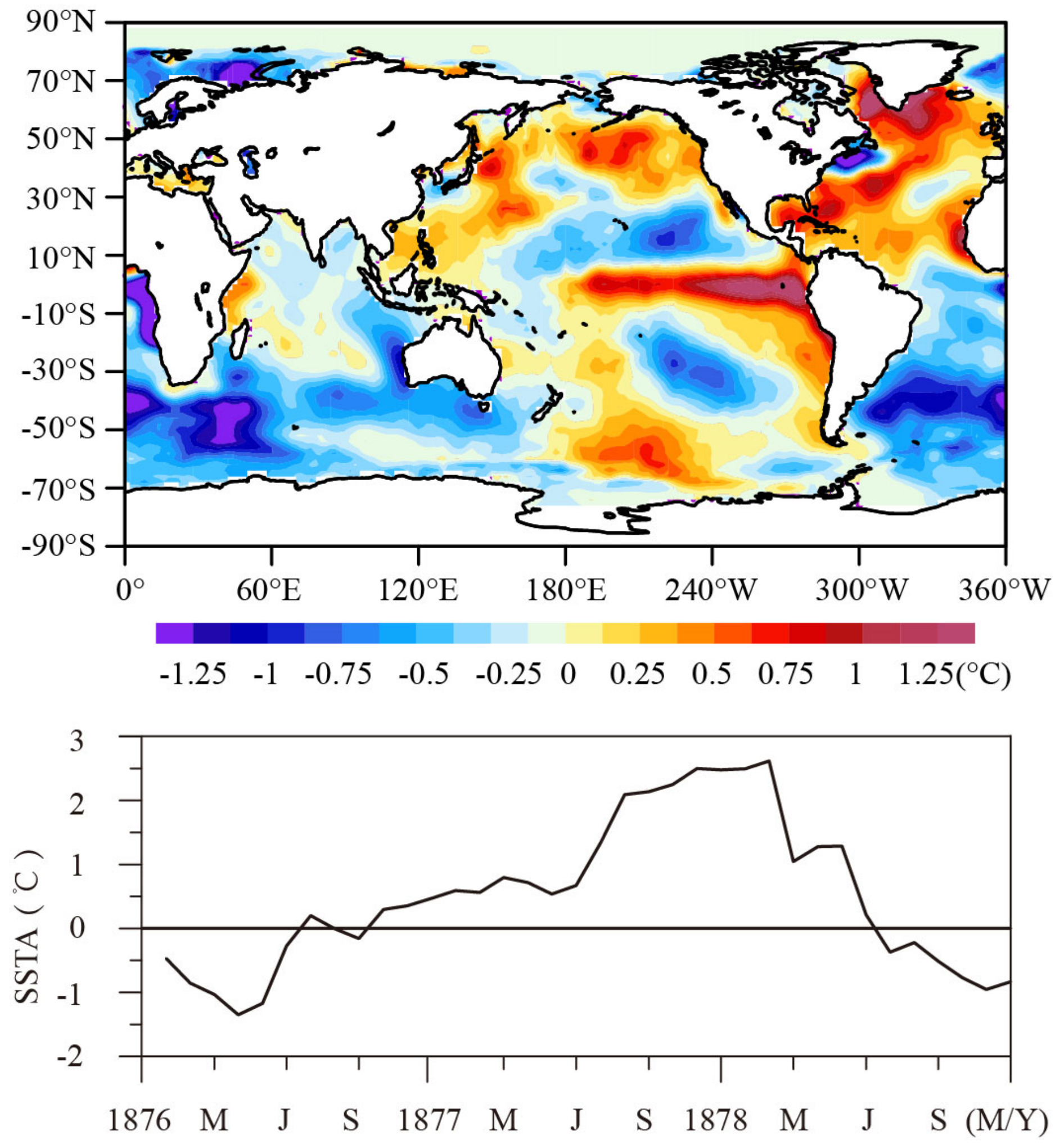

Figure 1

Anomaly of Sea Surface temperature during 1876-1878. The referenced period: 1971-2000; (a) global SSTA; (b) monthly SSTA of Niño 3.4 from January 1876 to December 1878; M, J and S indicate March, June and September. Note: The designations employed and the presentation of the material on this map do not imply the expression of any opinion whatsoever on the part of Research Square concerning the 
legal status of any country, territory, city or area or of its authorities, or concerning the delimitation of its frontiers or boundaries. This map has been provided by the authors.
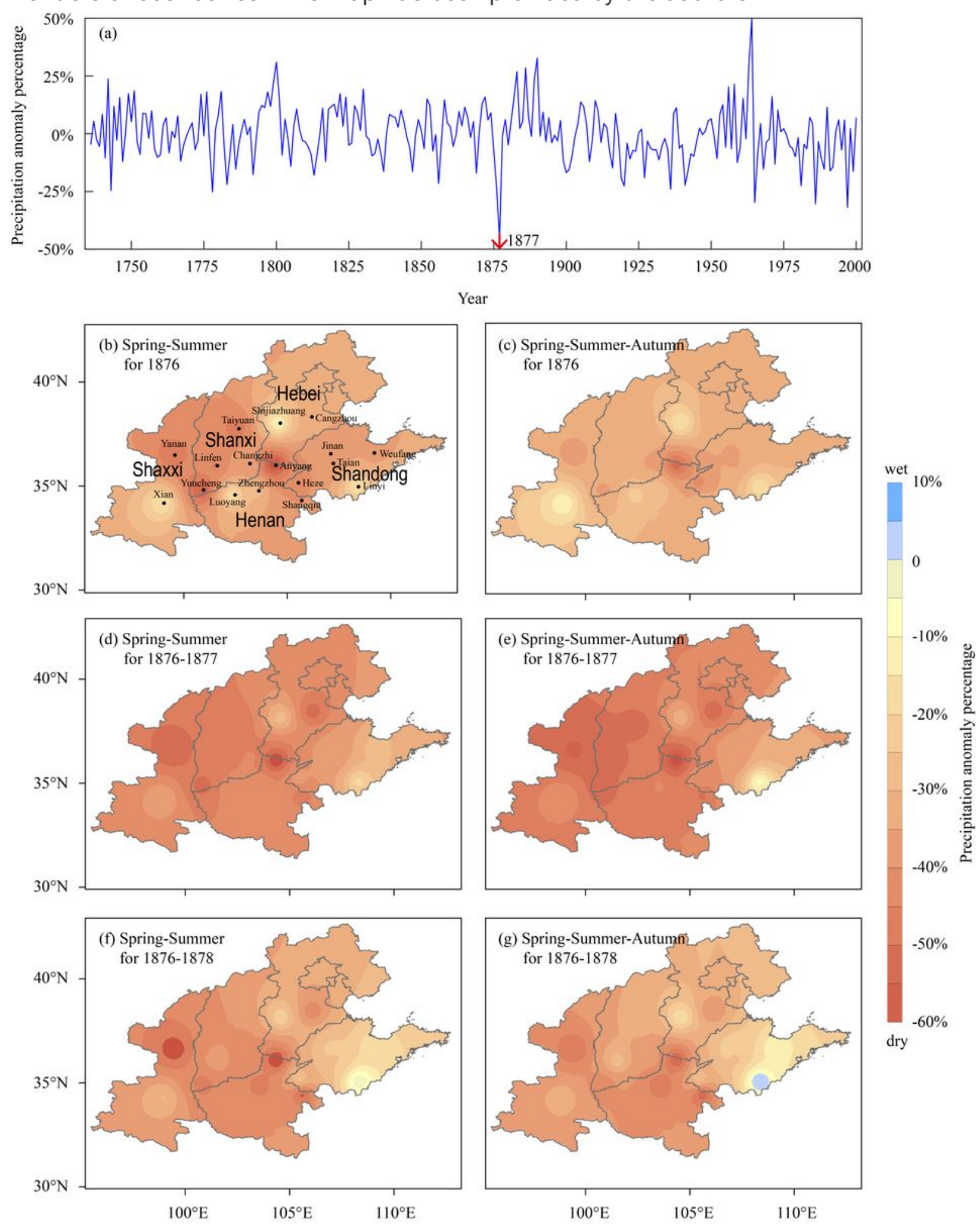

Figure 2

Regional average precipitation anomaly percentage (the mean value of 1851-2000 as referenced climatology) since the industrial revolution in North China (a) and accumulated seasonal precipitation anomaly percentage for 1876-1878 (b-g). Note: The designations employed and the presentation of the 
material on this map do not imply the expression of any opinion whatsoever on the part of Research Square concerning the legal status of any country, territory, city or area or of its authorities, or concerning the delimitation of its frontiers or boundaries. This map has been provided by the authors.
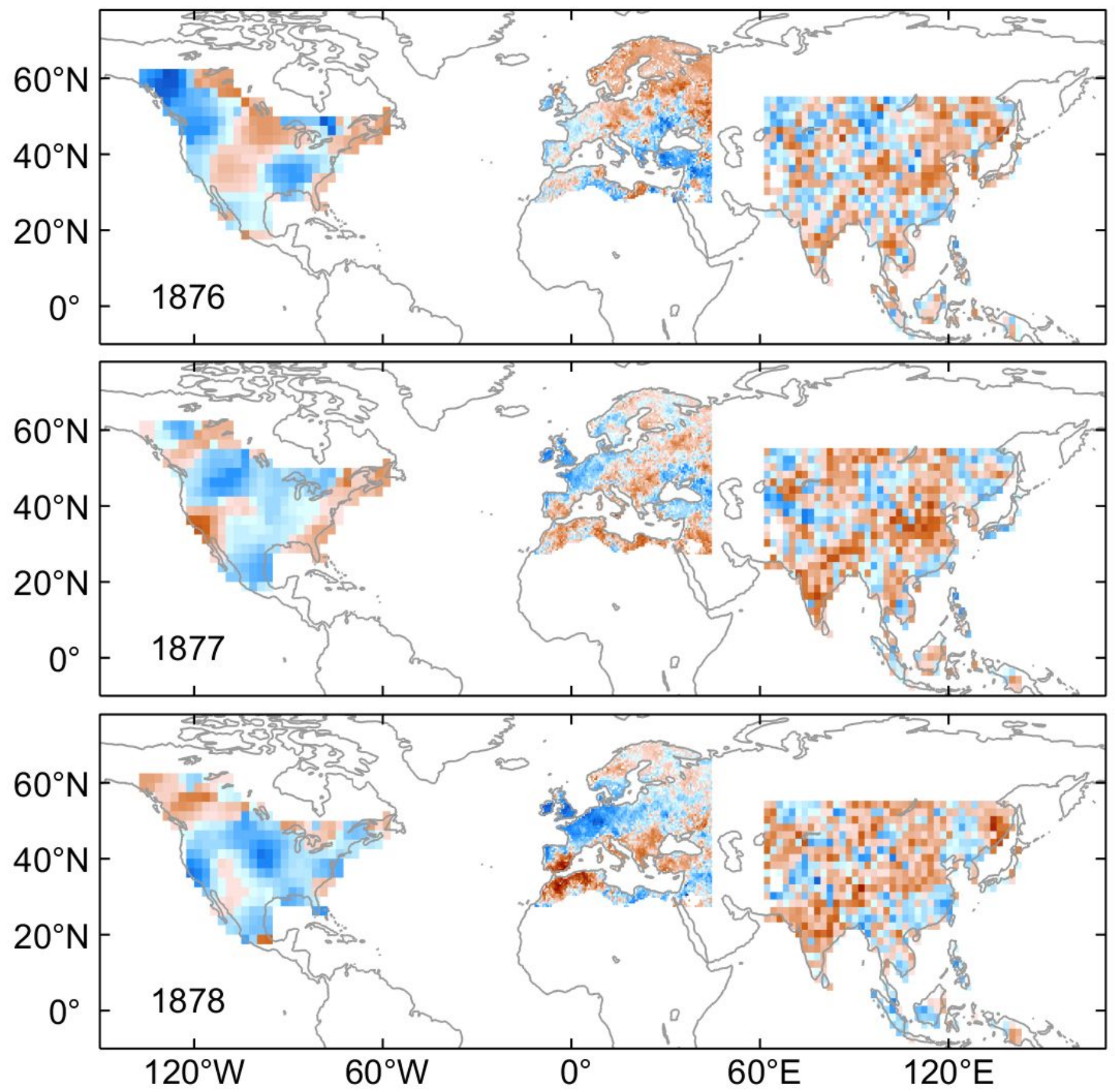

$-4 \quad-2$

0

2

4

Figure 3

Distribution of the 1876-1878 drought and intensity reconstructed from the NADA, OWDA and RAP datasets (the referenced period: 1851-2000). Note: The designations employed and the presentation of 
the material on this map do not imply the expression of any opinion whatsoever on the part of Research Square concerning the legal status of any country, territory, city or area or of its authorities, or concerning the delimitation of its frontiers or boundaries. This map has been provided by the authors.
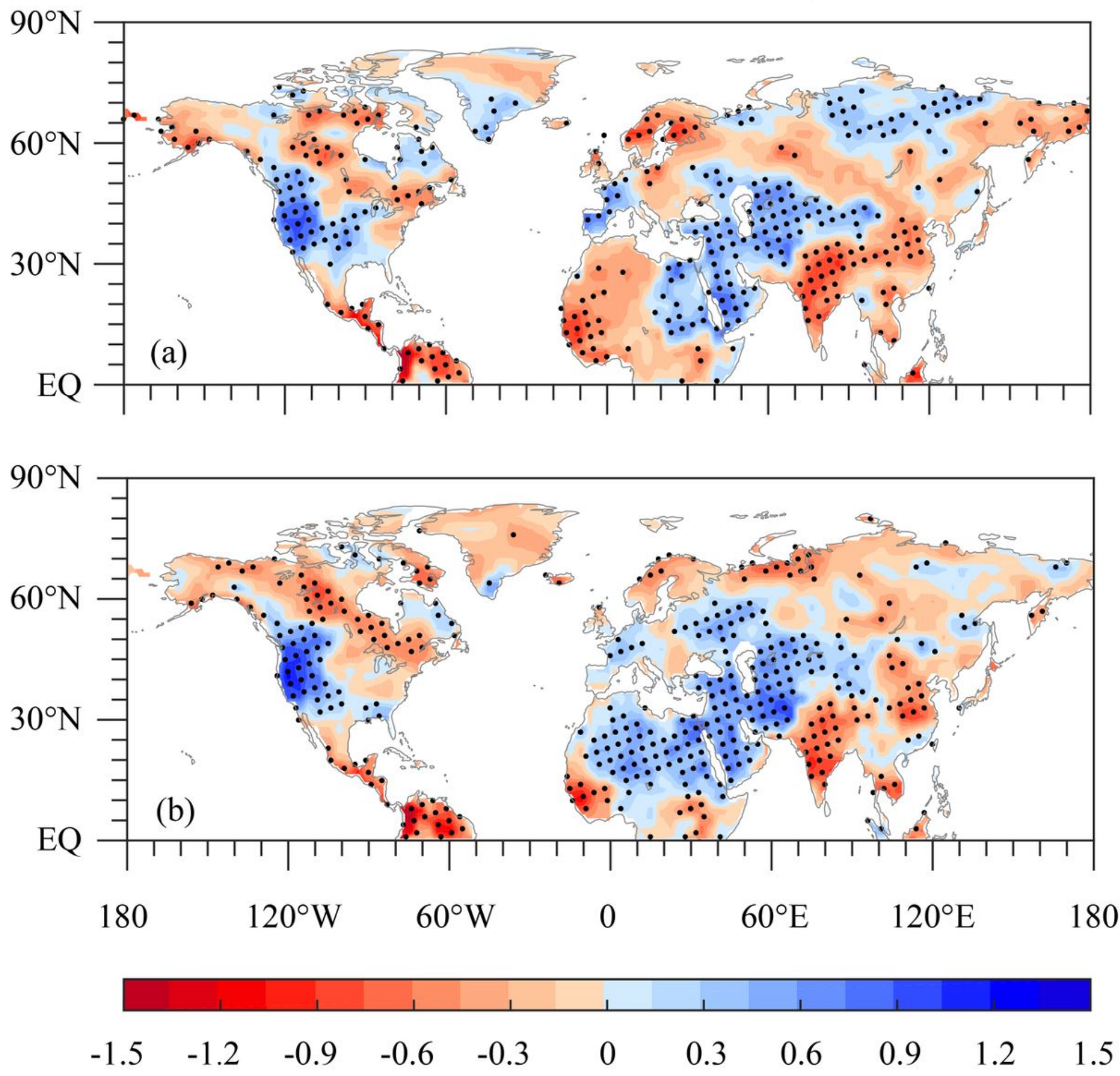

Figure 4

The hydroclimatic spatial patterns for El Niño + positive PDO phase (a) and El Niño + positive IOD phase (b) from HadCM3; The dry/wet areas at $95 \%$ confidence level were dotted. Note: The designations employed and the presentation of the material on this map do not imply the expression of any opinion whatsoever on the part of Research Square concerning the legal status of any country, territory, city or 
area or of its authorities, or concerning the delimitation of its frontiers or boundaries. This map has been provided by the authors.

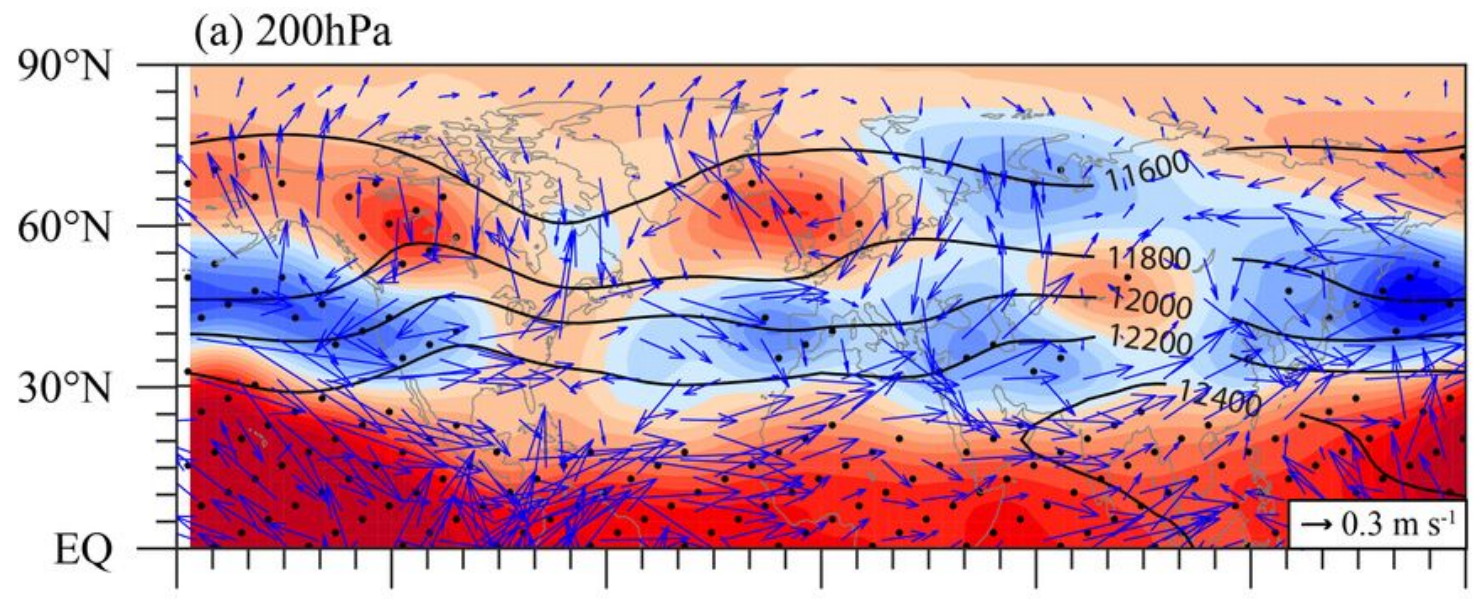

(b) $500 \mathrm{hPa}$
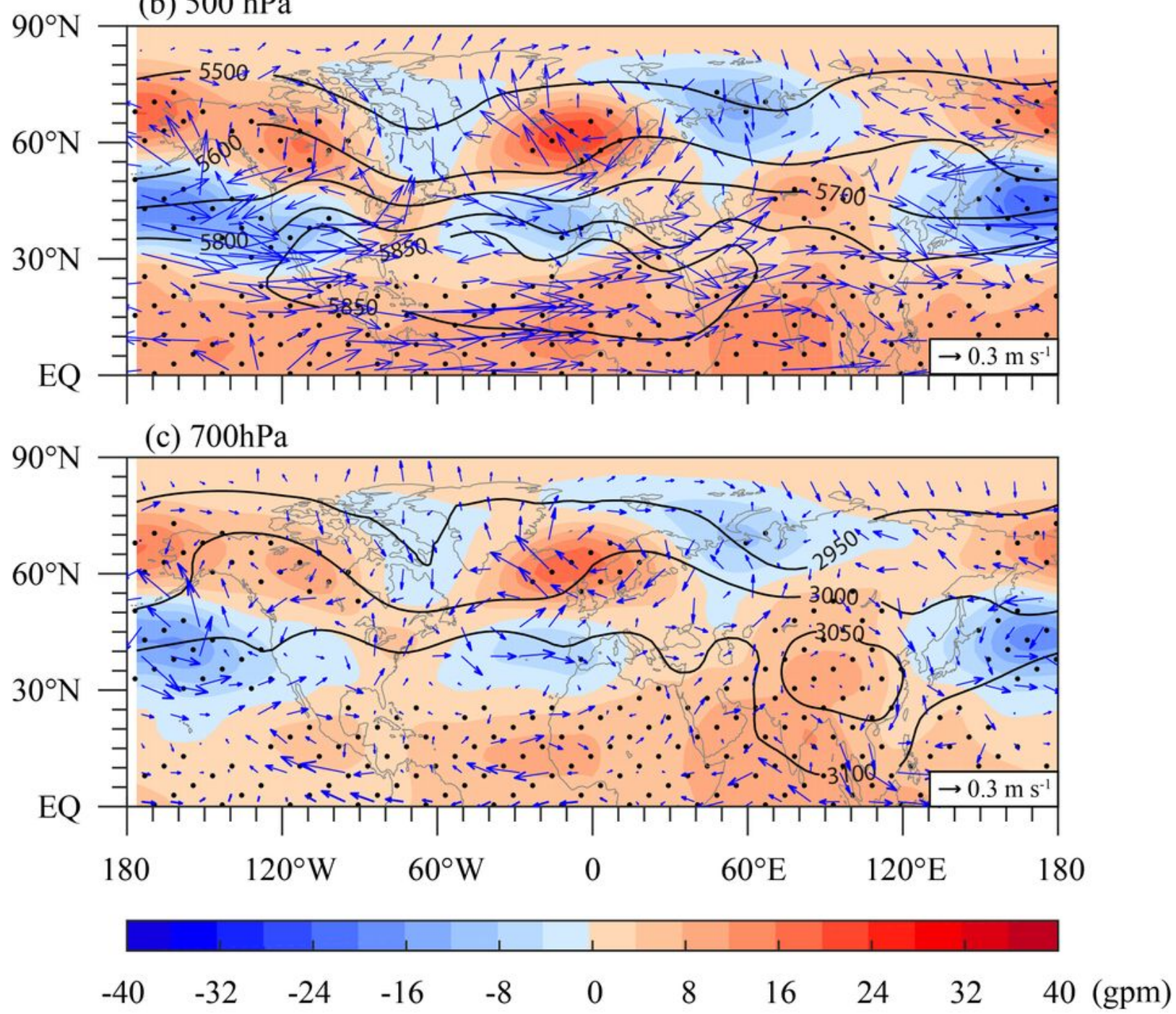

Figure 5

Spatial pattern of geopotential height anomaly and wind anomaly of $200 \mathrm{hPa}$ (a), $500 \mathrm{hPa}$ (b), and 700 hPa pressure level (c) at El Niño + positive PDO phase. The areas with obvious changes are indicated by black dots at $95 \%$ confidence level. Black lines are denoted that geopotential height climatology over 
1200-year of control simulation of HadCM3. Note: The designations employed and the presentation of the material on this map do not imply the expression of any opinion whatsoever on the part of Research Square concerning the legal status of any country, territory, city or area or of its authorities, or concerning the delimitation of its frontiers or boundaries. This map has been provided by the authors.
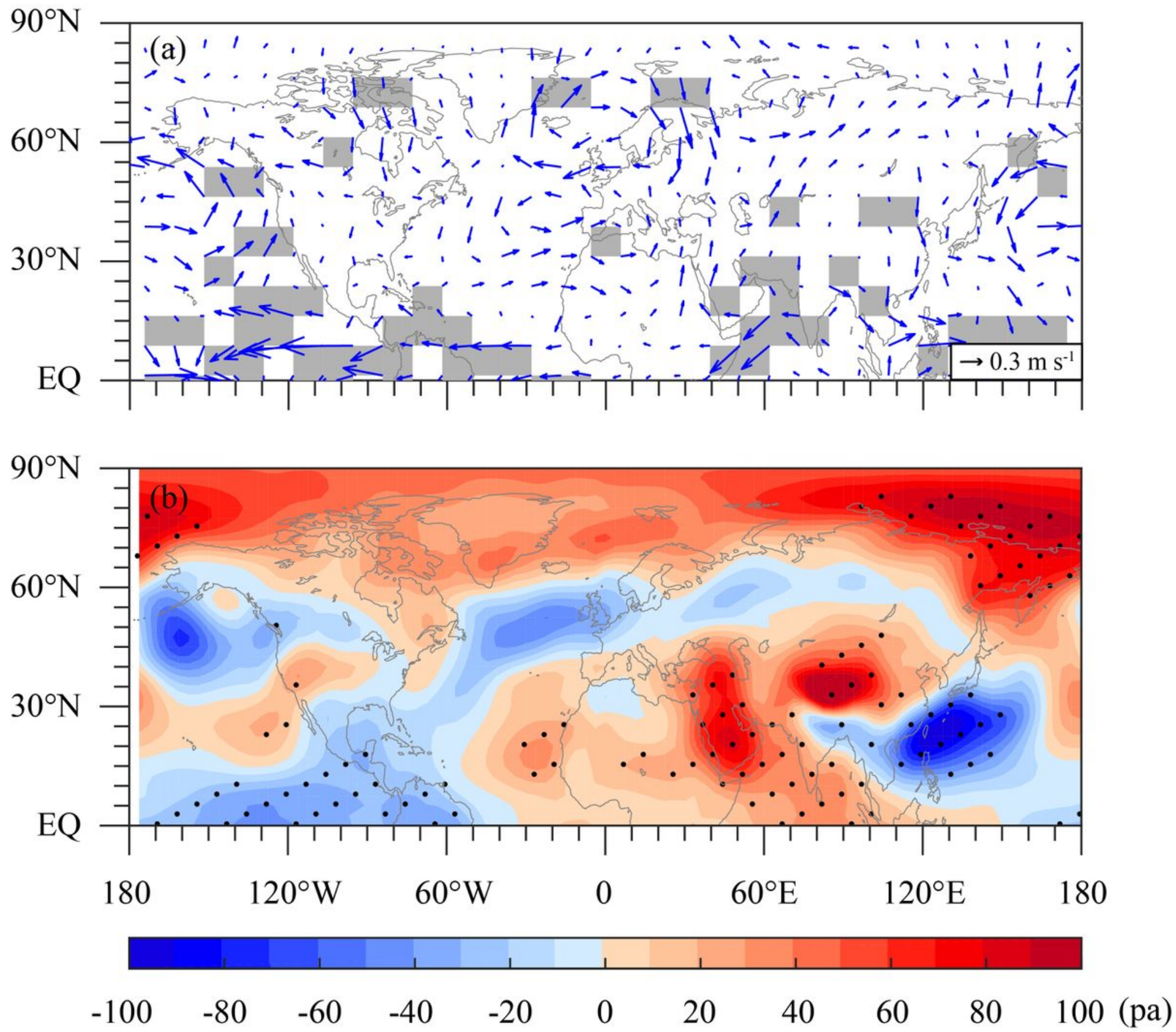

\section{Figure 6}

Spatial pattern of wind vector anomaly of $850 \mathrm{hPa}$ pressure level (a) in El Niño + positive PDO phase and sea level pressure anomaly (b). The obvious changes for wind field and sea level pressure are denoted by grey shadows and dots at $95 \%$ confidence level. Note: The designations employed and the presentation of the material on this map do not imply the expression of any opinion whatsoever on the part of Research Square concerning the legal status of any country, territory, city or area or of its authorities, or concerning the delimitation of its frontiers or boundaries. This map has been provided by the authors. 


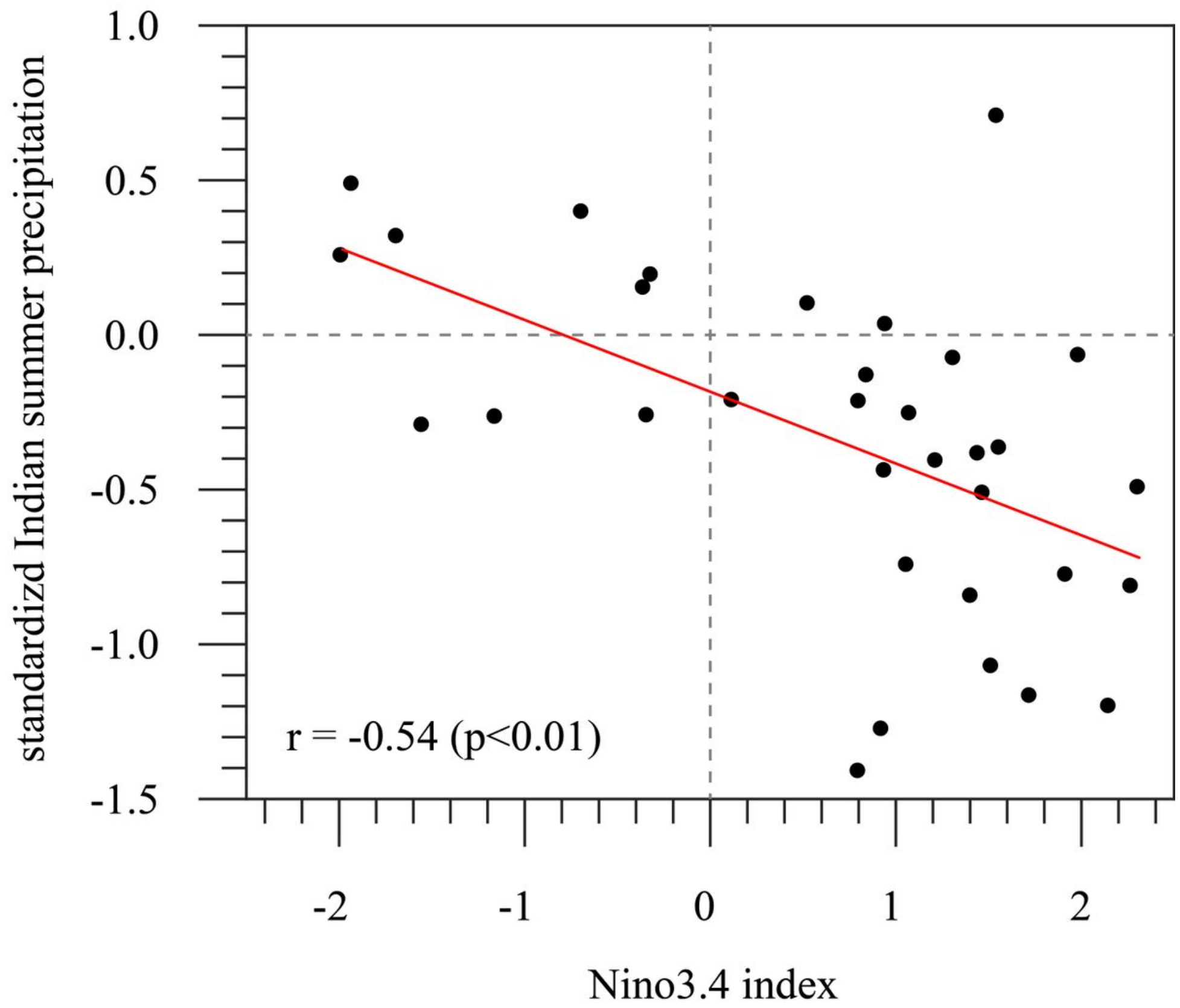

Figure 7

The relationship between Nino3.4 index and standardized Indian summer precipitation $\left(15-30^{\circ} \mathrm{N}, 70-90^{\circ} \mathrm{E}\right)$ for El Niño + positive PDO phase. The label of axis indicates the two previous, current and two post El Niño summer. 


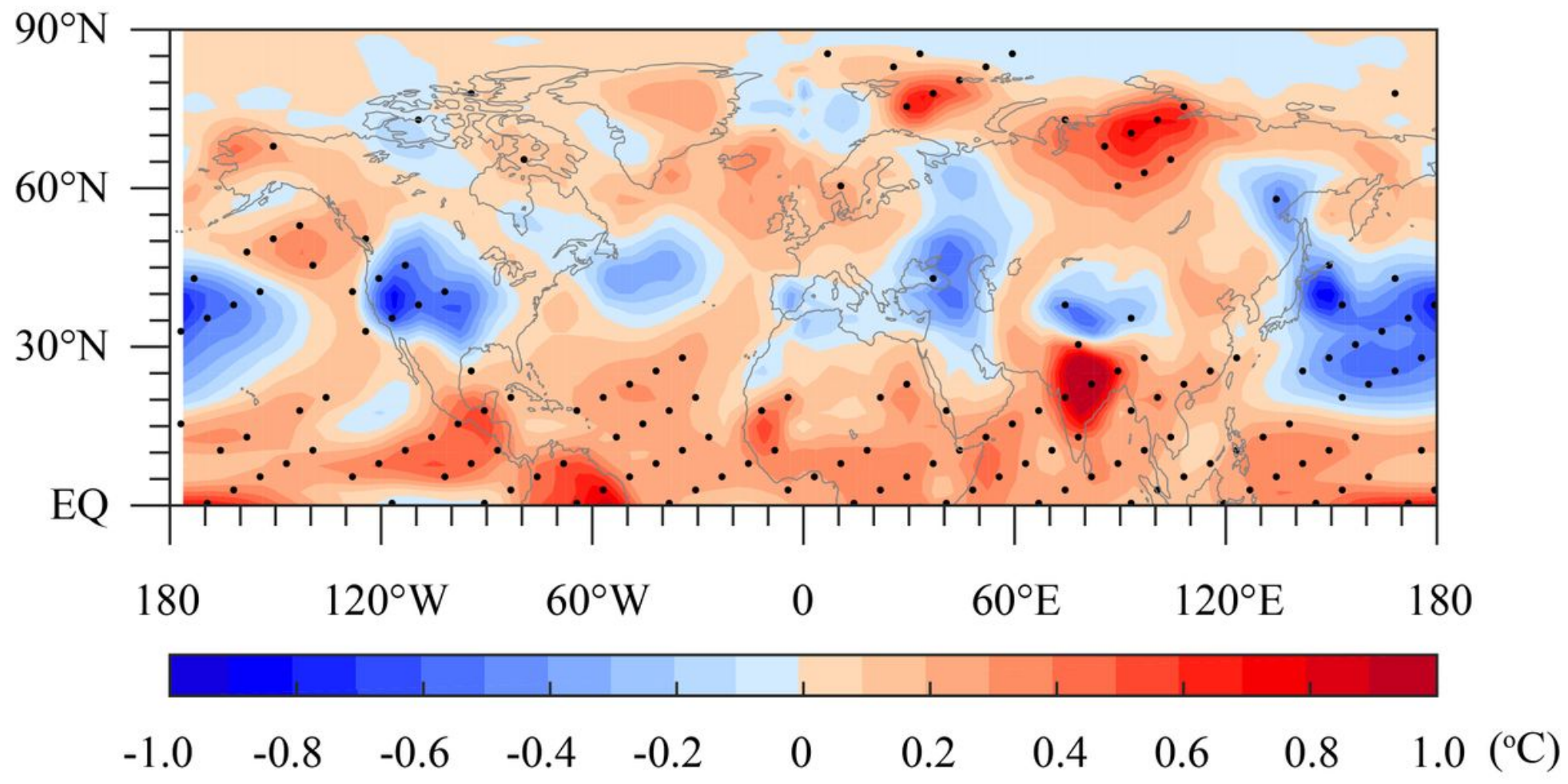

Figure 8

Same as Figure $6 \mathrm{~b}$, but for surface air temperature anomaly. Note: The designations employed and the presentation of the material on this map do not imply the expression of any opinion whatsoever on the part of Research Square concerning the legal status of any country, territory, city or area or of its authorities, or concerning the delimitation of its frontiers or boundaries. This map has been provided by the authors. 